\title{
Familial polyposis coli and its extracolonic manifestations
}

\author{
S B COHEN
}

From the Department of Medicine, Walton Hospital, Liverpool L9 $1 A E$

SUMmARY A detailed clinical study of 30 families with familial polyposis coli is presented. Seven 'isolated' cases are also described. It was found that some families did not exhibit any extracolonic manifestations, but the majority of families showed various numbers of members who had these manifestations of differing types and degrees. In view of the great variability within the members of a family, polyposis coli and the Gardner syndrome are probably both produced by one pleiotropic gene.

The occurrence of other neoplastic phenomena in association with polyposis coli has been considered. Many types of malignancy can occur in these patients and their families and the majority are probably fortuitous. The consistent finding of an association with medulloblastoma is such as to make this association of significance, but no reason is known for this. It is suggested that the term 'Turcot syndrome' should be used in a more restrictive manner than at present.

Polyposis coli, more correctly named multiple adenomatosis of the colon and rectum, is a disease, inherited as a Mendelian dominant trait, which progresses inevitably to carcinoma of the colon. Isolated cases were reported in the mid-19th century, but the first definitive account was from St Mark's Hospital, London, ${ }^{1}$ where the first register for the disease was started and further aspects of the condition were recognised. ${ }^{2-4}$ Polyposis coli has been described in all parts of the world and large series have been reported from Sweden ${ }^{5}$ and Japan. ${ }^{6}$ Many early reports ${ }^{7-9}$ of polyposis coli mention various extracolonic manifestations. Gardner and Richards ${ }^{10}$ recognised the syndrome and described a classical family. Initially, the extracolonic phenomena described were epidermoid cysts, osteomas, and fibromas, but later Gardner ${ }^{11}$ added dental abnormalities and desmoids.

In 1974, a register was started at the Johns Hopkins Hospital in Baltimore and an analysis is given of the first 30 families with polyposis coli. Cases were ascertained in two ways. Letters were sent to 7000 physicians in Maryland and the surrounding five states (Delaware, New Jersey, Pennsylvania, Virginia, West Virginia) and the district of Columbia, asking for the names of any patients in their practices who had intestinal polyposis. Approximately 200 replied stating that they had looked after such patients. Permission was

Received for publication 6 August 1981 requested from these physicians to approach the patient or, if he or she were dead, the closest living relative, to participate in the study.

Another method was to request from accredited hospitals in the area a list of all patients who had received treatment over the past 10 years for one of the hereditary polyposes. Patients and relatives were then approached and sent a medical and genealogical questionnaire. The pedigree was then sketched out in the appropriate direction. Hospitals and physicians were contacted to provide further details of diagnosis, pathology, treatment, etc. In some cases records could not be obtained because they had been lost, destroyed, etc. Investigation was offered to family members between 10 and 60 years of age, although these age limits were not strict.

\section{Investigations}

\section{CLINICAL EXAMINATION}

On the day of examination family members were seen at the hospital in the morning. A medical history was taken, particular note being made of the age of onset of any bowel symptoms and the presence of any skin lumps or cysts. A full clinical examination was performed.

\section{COLONOSCOPY}

Previous studies ${ }^{35}$ have stated that sigmoidoscopy alone is sufficient. The size of the adenoma is 
irrelevant for the diagnosis of polyposis coli, but it is very important in assessing the risk of a polyp becoming malignant. ${ }^{12}$ It is advisable, therefore, to try and assess the adenomas in the entire colon.

After intravenous premedication with atropine $0.6 \mathrm{mg}$, pethidine $50 \mathrm{mg}$, and a variable quantity of diazepam (usually 5 to $15 \mathrm{mg}$ ) colonoscopy was performed. Biopsies were taken from polyps. It was the aim in all cases to try to examine the entire colon, but sometimes this proved impossible. If excessive discomfort was shown by the patient the examination was stopped, as the majority would be re-examined at future dates for the possible development of adenomas and it was considered important to maintain their full co-operation.

\section{DENTAL EXAMINATION}

On recovery from the intravenous sedative the patient was examined by the dental geneticist (Dr L S Levin) and panoramic radiographs of the mandible and maxilla were taken.

\section{AIR CONTRAST BARIUM ENEMA}

On the same afternoon the patient had an air contrast barium enema in the Department of Radiology. No case of perforation occurred.

\section{DIAGNOSTIC CRITERIA}

\section{Epidermoid cysts}

Epidermoid cysts are common in the general population. The size and number of such cysts is variable, but the age of onset when they are associated with polyposis coli is lower than in the general population. ${ }^{13}$

\section{Osteomas}

The incidence of small osteomas (found on $x$-ray only) in the jaw in the general population is unknown and may vary with the population.

\section{Desmoid tumours}

These are exceedingly rare and their association with polyposis coli must be significant. The combination of colonic adenomas, epidermoid cysts, osteomas, and desmoids is unique to the Gardner syndrome.

\section{Results}

Thirty families with familial polyposis coli were investigated and 403 subjects were assessed, 200 males and 203 females. Among them 144 subjects had multiple adenomas, 68 males and 76 females (table 1).

The sample mean and variances of the age of onset of symptoms, the age of diagnosis of polyps, and the age of diagnosis of cancer are shown in table 2.

Histograms were constructed for the age of onset of symptoms and diagnosis of polyps in all subjects and for the probands alone. The histogram for the age of diagnosis of cancer in all subjects was constructed, but not for probands alone in view of the small number of such cases (figs $1,2,3,4,5$ ).

The age of diagnosis of epidermoid cysts is shown in table 3 and extracolonic manifestations are tabulated in tables 4 and 5. Details of the desmoid tumours and other abnormal fibrous tissue reactions are shown in table 6. Details of the five cases of brain tumour are shown in table 7 and associated tumours in table 8. Details of the seven 'single member families' are shown in table 9 and parental age of the seven 'isolated' cases of polyposis coli are shown in table 10.

\section{Discussion}

EXTRACOLONIC MANIFESTATIONS

The data are set out in tables 4 and 5. An analysis of the phenotypes in these 30 families shows that 14 families (173 subjects) had no extracolonic manifestations and 16 families (230 subjects) had such manifestations in several members. These 16 families have been split into seven groups according to which combination of extracolonic manifestation is present. The families' numbers are given. Table 4 shows the number of subjects known to have adenomas and the number of them who are reliably known to have extracolonic manifestations. Table 5 shows details of the extracolonic manifestations which occurred in 51 persons in the 16 families. Polyps are present in all but eight, of whom five are sufficiently young to have a high probability of developing them. Two developed the cysts as adults and they thus may be of no significance. The pedigrees of these 16 families are shown in the appendix. There is no evidence that these manifestations are transmitted by a parent of one particular sex. As examples, in family 1 , of the four people who had extracolonic manifestations, only one had all three lesions, one had cysts and osteomas, the third had only recurrent desmoids, and the fourth had only cysts. The remaining five members in that family with adenomas were not known to have any extracolonic manifestations.

Family 2 and family 4 are the two which most closely approximate to Gardner's kindred $109 .{ }^{10}$ In family 2, eight members had adenomas and all eight

TABLE 1 Total number of subjects in the 30 families and the number with adenomas

\begin{tabular}{lccl}
\hline & Males & Females & Total \\
\hline No of subjects in the 30 families & 200 & 203 & 403 \\
No of subjects with polyps & 68 & 76 & 144 \\
\hline
\end{tabular}


TABLE 2 Age of onset of symptoms, diagnosis of polyps, and diagnosis of cancer

\begin{tabular}{|c|c|c|c|c|}
\hline & & & Males & Females \\
\hline \multicolumn{5}{|l|}{ Age of onset of symptoms } \\
\hline All subjects & $\begin{array}{l}\text { Mean } \\
\text { Variance }\end{array}$ & $\begin{array}{r}29 \cdot 88 \\
160 \cdot 70\end{array}$ & $31 \cdot 93$ & $27 \cdot 83$ \\
\hline Probands & $\begin{array}{l}\text { Mean } \\
\text { Variance }\end{array}$ & $\begin{array}{r}27 \cdot 63 \\
125 \cdot 14\end{array}$ & $32 \cdot 10$ & $23 \cdot 91$ \\
\hline \multicolumn{5}{|c|}{ Age of diagnosis of polyps } \\
\hline All subjects & $\begin{array}{l}\text { Mean } \\
\text { Variance }\end{array}$ & $\begin{array}{r}26 \cdot 65 \\
148 \cdot 14\end{array}$ & $27 \cdot 32$ & $26 \cdot 64$ \\
\hline Probands & $\begin{array}{l}\text { Mean } \\
\text { Variance }\end{array}$ & $\begin{array}{c}28 \cdot 37 \\
129 \cdot 26\end{array}$ & $31 \cdot 25$ & $26 \cdot 35$ \\
\hline \multicolumn{5}{|c|}{ Age of diagnosis of cancer } \\
\hline All subjects & $\begin{array}{l}\text { Mean } \\
\text { Variance }\end{array}$ & $\begin{array}{r}38 \cdot 31 \\
117 \cdot 28\end{array}$ & $39 \cdot 56$ & $37 \cdot 12$ \\
\hline Probands & $\begin{array}{l}\text { Mean } \\
\text { Variance }\end{array}$ & $\begin{array}{l}35 \cdot 00 \\
60 \cdot 00\end{array}$ & $36 \cdot 83$ & $32 \cdot 25$ \\
\hline
\end{tabular}

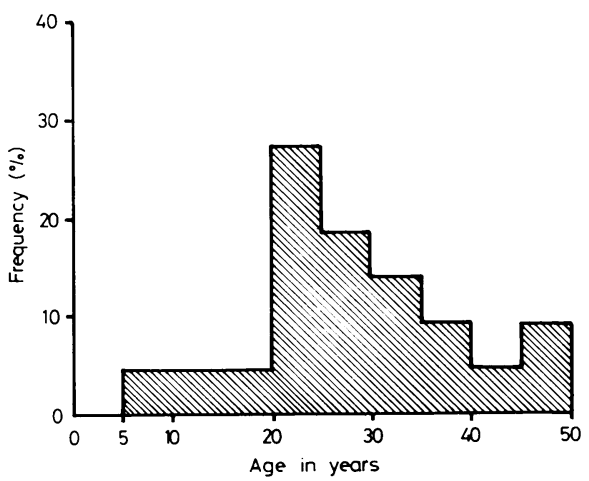

FIG 1 Frequency distribution of age of onset of symptoms in the probands. Mean: 27.6 years.

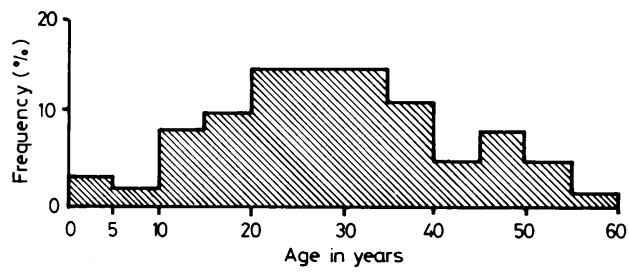

FIG 2 Frequency distribution of age of onset of symptoms in all subjects (including probands). Mean: 29.8 years.

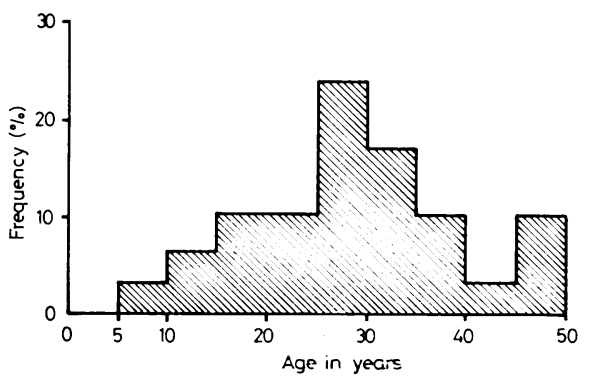

FIG 3 Frequency distribution of age of diagnosis of polyps in the probands. Mean: $28 \cdot 3$ years.

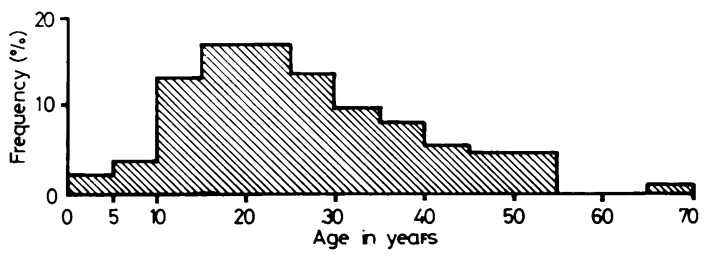

FIG 4 Frequency distribution of age of diagnosis of polyps in all subjects (including probands). Mean: 26.6 years.

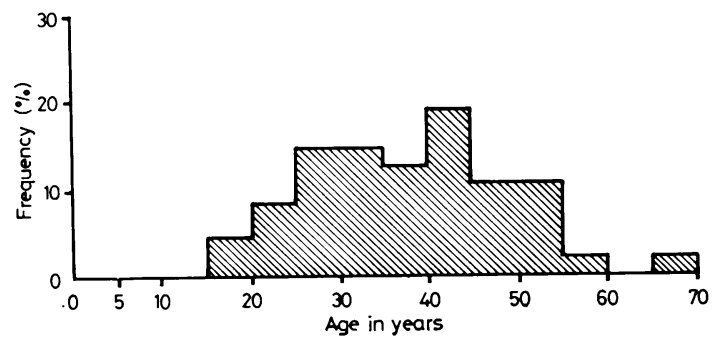

FIG 5 Frequency distribution of age of diagnosis of carcinoma in all subjects. Mean: $38 \cdot 3$ years.

TABLE 3 Age of diagnosis of epidermoid cysts

\begin{tabular}{ll}
\hline Family No & Age of diagnosis of individual members (years) \\
\hline 1 & $27,18,11$ \\
2 & $24,16,12,12,9,7,6,6,2$ \\
3 & 16 \\
4 & 44,12 \\
7 & $28,17,12,12,8,8,7,5,4,3$ \\
13 & 13,9 \\
14 & 10 \\
18 & 45,36 \\
26 & 20 \\
27 & 10 \\
28 & 8 \\
\hline & Two subjects with cysts omitted, as the age of onset was very indefinite
\end{tabular}

TABLE 4 Details of the 16 families with extracolonic manifestations

\begin{tabular}{|c|c|c|c|c|}
\hline Group & $\begin{array}{l}\text { Types of } \\
\text { extracolonic } \\
\text { manifestations } \\
\text { in the family }\end{array}$ & $\begin{array}{l}\text { Family } \\
\text { No }\end{array}$ & $\begin{array}{l}\text { No of subjects } \\
\text { with polyps }\end{array}$ & $\begin{array}{l}\text { No of subjects } \\
\text { with polyps plus } \\
\text { extracolonic } \\
\text { manifestations }\end{array}$ \\
\hline 1 & $\begin{array}{l}\text { Cysts } \\
\text { Osteomas } \\
\text { Desmoids }\end{array}$ & $\begin{array}{r}1 \\
2 \\
4 \\
7 \\
14\end{array}$ & $\begin{array}{r}8 \\
8 \\
3 \\
15 \\
3\end{array}$ & $\begin{array}{l}3 \\
8 \\
3 \\
9 \\
3\end{array}$ \\
\hline 2 & $\begin{array}{l}\text { Cysts } \\
\text { Osteomas }\end{array}$ & $\begin{array}{r}26 \\
3 \\
27\end{array}$ & $\begin{array}{l}6 \\
2 \\
2\end{array}$ & $\begin{array}{l}4 \\
1 \\
1\end{array}$ \\
\hline 3 & $\begin{array}{l}\text { Cysts } \\
\text { Desmoids }\end{array}$ & 18 & 4 & 2 \\
\hline 4 & $\begin{array}{l}\text { Osteomas } \\
\text { Desmoids }\end{array}$ & 5 & 7 & 2 \\
\hline 5 & Desmoids & $\begin{array}{l}19 \\
22\end{array}$ & $\begin{array}{l}6 \\
4\end{array}$ & $\begin{array}{l}1 \\
1\end{array}$ \\
\hline 6 & Cysts & $\begin{array}{l}13 \\
28\end{array}$ & $\begin{array}{l}3 \\
3\end{array}$ & $\begin{array}{l}1 \\
1\end{array}$ \\
\hline 7 & Osteomas & $\begin{array}{r}11 \\
8\end{array}$ & $\begin{array}{l}9 \\
6\end{array}$ & $\begin{array}{l}1 \\
2\end{array}$ \\
\hline
\end{tabular}


TABLE 5 Details of the extracolonic manifestations in the 51 subjects

\begin{tabular}{|c|c|c|c|c|c|c|c|}
\hline Family & Subject & Cysts & Osteomas & Desmoids & Polyps & Present age & Age at cyst occurrence \\
\hline \multirow[t]{4}{*}{1} & II.1 & + & + & & + & & \\
\hline & II. 4 & + & & + & + & & \\
\hline & 11.8 & + & + & + & + & & \\
\hline & III.5 & + & & & 0 & 13 & 11 \\
\hline \multirow[t]{9}{*}{2} & II. 2 & + & + & & + & & \\
\hline & II. 3 & + & + & & + & & \\
\hline & II. 6 & & + & + & + & & \\
\hline & III.1 & + & + & + & + & & \\
\hline & III.2 & + & & & 0 & 37 & 24 \\
\hline & III.3 & + & + & + & + & & \\
\hline & III.4 & + & + & & + & & \\
\hline & III.5 & + & + & & + & & \\
\hline & IV.1 & + & + & & + & & \\
\hline 3 & II.1 & + & + & & + & & \\
\hline \multirow[t]{3}{*}{4} & II.4 & + & + & & + & & \\
\hline & II. 5 & & & + & + & & \\
\hline & III. 2 & + & + & & + & & \\
\hline \multirow[t]{2}{*}{5} & I.1 & & + & & + & & \\
\hline & 1.5 & & + & + & + & & \\
\hline \multirow[t]{12}{*}{7} & II.1 & & & + & + & & \\
\hline & II. 2 & + & + & & + & & \\
\hline & II. 4 & + & & & 0 & 38 & 28 \\
\hline & II. 5 & + & & & + & & \\
\hline & II. 9 & + & & & + & & \\
\hline & II.10 & + & & & + & & \\
\hline & III.1 & & + & & + & & \\
\hline & III. 2 & + & + & & 0 & 17 & 7 \\
\hline & III. 3 & + & & & 0 & 23 & 3 \\
\hline & III.5 & + & & & + & & \\
\hline & III.8 & + & & & + & & \\
\hline & III.11 & + & + & & + & & \\
\hline \multirow[t]{2}{*}{8} & II.3 & & + & & + & & \\
\hline & III. 3 & & + & & + & & \\
\hline 11 & II.9 & & + & & + & & \\
\hline \multirow[t]{2}{*}{13} & III. 2 & + & & & + & & \\
\hline & IV.2 & + & & & 0 & 11 & 9 \\
\hline \multirow[t]{3}{*}{14} & II. 2 & + & + & & + & & \\
\hline & III.1 & & & + & + & & \\
\hline & III.4 & + & + & & + & & \\
\hline \multirow[t]{2}{*}{18} & II.1 & + & & & + & & \\
\hline & II. 5 & + & & + & + & & \\
\hline 19 & I.3 & & & + & + & & \\
\hline 22 & III.1 & & & + & + & & \\
\hline 26 & II.1 & + & & & + & & \\
\hline \multirow{3}{*}{ i } & II. 3 & & + & & + & & \\
\hline & II.4 & & + & & + & & \\
\hline & II.6 & & + & & + & & \\
\hline \multirow{4}{*}{28} & II.1 & + & + & & + & & \\
\hline & II. 2 & + & & & + & & \\
\hline & II. 3 & + & & & 0 & 55 & Childhood \\
\hline & III.3 & + & & & 0 & 27 & 8 \\
\hline
\end{tabular}

TABLE 6 Details of desmoid tumours and abnormal fibrosis

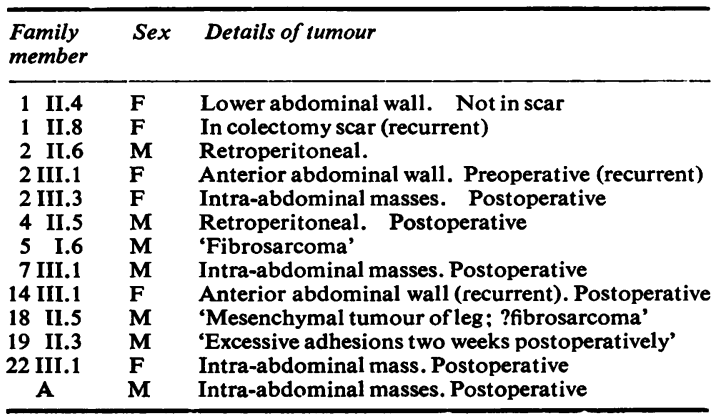

had extracolonic manifestations; only two had all three possible lesions. Family 4 is similar, but none of the three affected subjects, all with extracolonic manifestations, exhibited all three lesions. In family 7 , cysts were the predominant extracolonic manifestation; osteomas were less common and were not conspicuous clinically, and only one member had a desmoid tumour. This family, therefore, resembles that described by Oldfield, ${ }^{9}$ which led to 'Oldfield syndrome' being considered as a special sub-group. McAdam and Goligher, ${ }^{14}$ following up these families, found that at least one member had osteomas in the jaw on $x$-ray, and therefore this family can be considered as an example of the 
TABLE 7 Details of the five cases of brain tumour

\begin{tabular}{llllll}
\hline $\begin{array}{l}\text { Family } \\
\text { No }\end{array}$ & Sex & $\begin{array}{l}\text { Age at } \\
\text { death } \\
(y r)\end{array}$ & $\begin{array}{l}\text { Parent with } \\
\text { polyposis }\end{array}$ & $\begin{array}{l}\text { Necropsy } \\
\text { performed }\end{array}$ \\
\hline 4 & F & $5 \frac{1}{2}$ & Father & Medulloblastoma & Yes \\
5 & F & 6 & Mother & Medulloblastoma & Yes \\
7 & M & 24 & Mother & Cerebellar cyst & No \\
13 & F & 3 & Mother & 'Brain tumour' & $?$ \\
22 & F & 13 & Father & 'Brain stem tumour' & No \\
\hline
\end{tabular}

TABLE 8 Associated tumours in the familial polyposis coli families (excluding desmoids)

\begin{tabular}{|c|c|c|c|}
\hline Associated tumour & Family & Associated tumour & Family \\
\hline $\begin{array}{l}\text { Carcinoma of uterus } \\
\text { Ovarian cyst }\end{array}$ & 1 & $\begin{array}{l}\text { Cerebral tumour- } \\
\text { died at } 30 \text { 'after a } \\
\text { head injury' }\end{array}$ & 13 \\
\hline $\begin{array}{l}\text { Carcinoma of liver } \\
\text { Duodenal ulcer }\end{array}$ & & Cerebral tumour & \\
\hline $\begin{array}{l}\text { Gastric ulcer } \\
\text { Lipoma }\end{array}$ & 2 & Lung carcinoma & 16 \\
\hline Cerebral tumour & 4 & $\begin{array}{l}\text { Carcinoma of bladder } \\
\text { Carcinoma of vulva }\end{array}$ & 20 \\
\hline Cerebral tumour & 5 & Sarcoma of jaw & 21 \\
\hline Lipoma & 6 & Cerebral tumour & 22 \\
\hline $\begin{array}{l}\text { Thyroid adenoma } \\
\text { Leiomyoma of ileum } \\
\text { Carcinoma of ovaries }\end{array}$ & & $\begin{array}{l}\text { Leukaemia } \\
\text { Duodenal ulcer }\end{array}$ & 23 \\
\hline $\begin{array}{l}\text { Lipoma } \\
\text { Cerebral tumour } \\
\text { Congenital hydrocephalus } \\
\text { Congenital hydrocephalus }\end{array}$ & 7 & $\begin{array}{l}\text { Epithelioma of chest } \\
\text { Carcinoma of pancreas } \\
\text { Basal cell carcinoma } \\
\text { of face }\end{array}$ & 24 \\
\hline $\begin{array}{l}\text { Malignant melanoma } \\
\text { Cerebral tumour-no } \\
\text { details known }\end{array}$ & 8 & $\begin{array}{l}\text { Papillary carcinoma } \\
\text { of thyroid } \\
\text { Ovarian carcinoma }\end{array}$ & 28 \\
\hline $\begin{array}{l}\text { Carcinoma of pancreas } \\
\text { Peptic ulcer }\end{array}$ & 11 & Carcinoma of stomach & 30 \\
\hline $\begin{array}{l}\text { Ovarian cystadenoma } \\
\text { Basal cell carcinoma } \\
\text { of face } \\
\text { Sertoli cell tumour } \\
\text { of testis } \\
\text { Hypernephroma } \\
\text { Congenital hydronephrosis } \\
\text { Ovarian cyst }\end{array}$ & 12 & & \\
\hline
\end{tabular}

TABLE 10 Parental age in isolated cases of polyposis coli

\begin{tabular}{lllllll}
\hline & \multicolumn{2}{l}{ Mother's age } & & \multicolumn{2}{l}{ Father's age } \\
\cline { 2 - 3 } \cline { 5 - 6 } \cline { 5 - 6 } & Mean & $S D$ & & Mean & $S D$ \\
\hline Isolated polyposis coli cases & 22.8 & 5.6 & & 26.0 & 6.4 \\
General population & 26.5 & 6.0 & & 29.8 & 6.9 \\
\hline
\end{tabular}

Gardner syndrome. It seems that the term 'Oldfield syndrome' is probably best discarded, as it is an unnecessary enlargement of an already difficult clinical field.

Groups 2, 3, and 4 are also well accepted examples of the Gardner syndrome, and details of the five families who fall into these three groups are shown in tables 4 and 5. Group 5 is more controversial, in that the only extracolonic manifestation was a desmoid tumour, and this only occurred in one member of each of the two families. However, the extreme rarity of both conditions (multiple colonic adenomas and desmoid tumours) makes it reasonable to put these two families under the heading of the Gardner syndrome. Finally, groups 6 and 7 are certainly the weakest to be considered, and it must be regarded as dubious that group 7 can be called the Gardner syndrome. In group 6 , family 13 is included with confidence as the subjects who had epidermoid cysts developed them in childhood.

Thus, these figures support the findings of the Swedish study ${ }^{5}$ that there are families in whom, even after the most strict scrutiny, no extracolonic manifestations are discovered.

At the other extreme are families similar to Gardner's kindred 109, where all affected members have extracolonic manifestations which are gross and obvious. However, this type of family seems to be unusual. Bussey ${ }^{4}$ reports no such family in the St Mark's group of 200 families. Alm and Licznerski ${ }^{5}$ did not find one subject in 80 families who exhibited

TABLE 9 Details of isolated cases ('single member families')

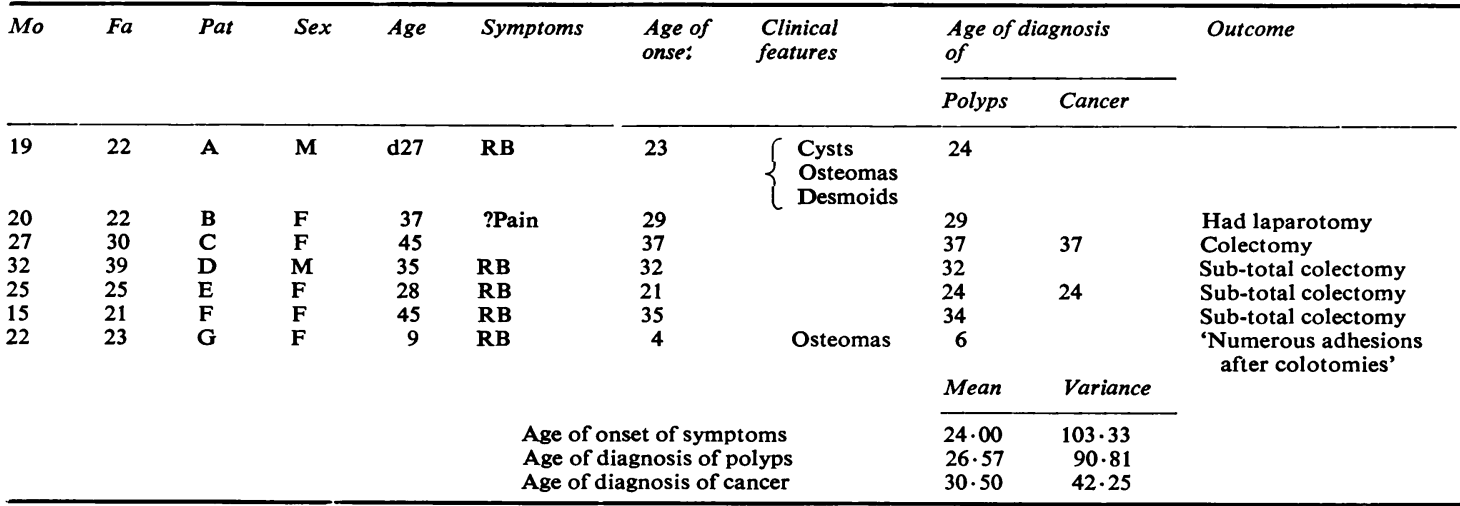

Mo = age of mother at patient's birth; $\quad$ Fa = age of father at patient's birth; $\quad$ Pat $=$ patient; $\quad$ RB = rectal bleeding. 
all three manifestations. It is far more common to find that in individual families some members have extracolonic manifestations associated with the adenomas, and other members only have adenomas. Even those members who have extracolonic manifestations may vary greatly as to which features and in what combination they have them.

Recent studies by Danes ${ }^{15}$ have shown increased tetraploidy in cultured skin fibroblasts in some subjects from families with the Gardner syndrome, families with familial polyposis coli, and in $7 \%$ of people who were not considered to have an increased risk of colonic cancer, but no definite difference has yet been found distinguishing the Gardner syndrome from polyposis coli.

\section{OTHER FEATURES}

Age and sex

No sex difference was found, as might be expected in a disease inherited as a Mendelian dominant trait. A similar finding has been described previously. ${ }^{35}$

\section{Age of onset data}

The age of onset data confirm the findings of previous studies, particularly in relation to the early onset of cancer of the colon. Histograms constructed for the age of onset data did not show any bimodality. This is in agreement with the Swedish study, ${ }^{5}$ but differs from Veale ${ }^{3}$ who based his 'modifying gene' hypothesis on this fact. The lack of bimodality is evidence against the hypothesis, although not conclusive. The age of onset of epidermoid cysts (table 3) is probably inaccurate, as many factors are involved in being aware of small cysts and in many cases the cysts had been removed years earlier.

Nevertheless, a mean of 15 years is in agreement with a previous study. ${ }^{13}$ Most of the cysts in these families were not large and in no subject were they numerous. This contrasts to some of Gardner's families who had gross disfiguring cysts.

\section{Symptoms}

The commonest presenting symptom was rectal bleeding. Other symptoms were much less common, mainly being the result of intestinal obstruction from cancer.

\section{Racial difference}

No definite racial difference has yet been described in the incidence of the Gardner syndrome. In this study, three of the 30 families and one of the seven single member families were American Negroes. No extracolonic manifestations were found, but two of these families were not fully co-operative and the number is too small to draw any firm conclusions.

\section{Diagnosis}

Biopsy of polyps is essential as many other polyps besides adenomas can inhabit the colon. ${ }^{16}$ The number of adenomas required for the diagnosis of polyposis coli has been stated to be over $100 .^{4}$ This, however, cannot be accepted at a clinical level. The number of adenomas must be considered in relation to the patient's age and the family history. Two or three adenomas in a 10-year-old must be significant, particularly if he is from an affected family.

\section{Treatment}

Proven cases of polyposis coli were treated with a total colectomy. The rectum was retained if there was no evidence of cancer, only a few adenomas present, and the patient was prepared to attend for regular follow-up sigmoidoscopies to assess progress of the adenomas.

\section{Brain tumours}

Crail $^{17}$ reported the occurrence of a papillary carcinoma of the thyroid gland, 100 small polyps of the colon, and a medulloblastoma in a 24-year-old male; no family history was given. Turcot $e t a l^{18}$ described a brother and sister aged 15 and 13, who presented with symptoms of polyposis coli and who later died from a medulloblastoma and a frontal glioblastoma, respectively. There was no family history suggesting polyposis coli. Baughman et al ${ }^{19}$ reported a family with four sibs who had gliomas. Two girls aged 12 and 21 had two rectal polyps and one male aged 25 had 24 polyps and had had a colonic carcinoma removed at the age of 20 . The fourth sib, aged 12, died without bowel symptoms and had no necropsy. There was no other family history of polyposis coli and the parents were not related.

A large study in Sweden ${ }^{5}$ included three cases of brain tumours in 1017 family members. None had bowel investigations, all were male, and their ages were 6,8 , and 25 years. Each had one parent who had multiple adenomatosis of the colon. The 8-yearold child had a medulloblastoma. The histology of the other two brain tumours is unknown. In the St Mark's 214 families with polyposis coli, two cases of brain tumour were found. ${ }^{4} A$ boy of 14 had a few rectal polyps and died at 17 with a medulloblastoma. A boy of 24, not known to have a bowel lesion, died from a medulloblastoma. In both cases the mother had multiple colonic adenomatosis. Yaffee ${ }^{20}$ described a case of a woman with gastric adenomas and epidermal cysts. A maternal uncle, who died in his eighties, had benign polyps of the colon (one showed carcinomatous degeneration) and a large frontal glioblastoma.

The data in the present study are given in table 7 In all cases one parent of each affected child had 
polyposis coli. None of the five with brain tumours was known to have polyps, which is not surprising in view of their comparative youth. Two of them had necropsies and one case of a cerebellar cyst is included.

This is the first time such a tumour has been described in association with polyposis coli and it is included partly for this reason and because a medulloblastoma, despite its name, develops from the cerebellum. Four of these five cases occurred in families in which other, commoner, extracolonic lesions occurred. The cerebellar cyst occurred in a family remarkable for the frequent early occurrence of skin cysts (family 7).

Medulloblastoma affects males 4:3 times more frequently than females. ${ }^{21}$ Fifty percent occur in the first decade, with a second peak at about 20 to 24 years of age. They form about $11 \%$ of all intracranial tumours of neuroepithelial origin. ${ }^{22}$ Two of our cases were confirmed at necropsy as being medulloblastomas. Two are of unknown histology, but case 5 is almost certainly another example, having been clinically designated a 'brain stem tumour'. Case 4 is more speculative; she died aged 3 and no further details of the brain tumour are available, since the death occurred in the 1930s.

The occurrence of the rare medulloblastoma in families with polyposis coli is unlikely to be fortuitous. The incidence of cerebral tumours in the USA is $4 \cdot 4 / 100000$ population per year. ${ }^{23}$ Our cases occurred in a total of $\mathbf{4 0 3}$ family members. No reason is known for this association.

The term 'Turcot syndrome' has been given to the association of polyposis coli and any primary brain tumour. There is a considerable difference, however, between his family ${ }^{18}$ and the brain tumours encountered in the Stockholm, London, and Baltimore studies. Turcot's sibs had parents who were phenotypically normal and were third cousins. A recent Japanese case report ${ }^{24}$ is of a family similar to Turcot's. The parents did not have colonic polyps and were first cousins. Both affected daughters had an astrocytoma and colonic adenomas. The family of Baughman et al 19 $^{19}$ isimilar to Turcot's, but the parents were not known to be related.

All the other families have had a parent with polyposis coli and in most cases the child's colon was not known to be diseased. It would seem advisable not to use the term 'Turcot syndrome' for all types of brain tumour associated with polyposis coli.

It is relevant to draw attention to the two young daughters of the proband of family 7 , who both died from the effects of hydrocephalus. Hydrocephalus has not previously been associated with the Gardner syndrome, but it would not be surprising if the abnormal fibrous tissue affected the nervous system, producing gliosis which could have been responsible for the hydrocephalus; no tumour was found at investigation. Family 7 included other members with abnormal fibrous tissue reaction. A report from Tokyo $^{25}$ described a male, with no significant family history, who had skull osteomas, colonic adenocarcinoma, and colorectal polyps. He had a craniotomy for a metastatic adenocarcinoma, but was reinvestigated a few months later having developed signs of raised intracranial pressure; a postoperative abnormal hyperplasia of the dura had developed.

\section{Other associated tumours}

Many different types of benign and malignant tumours have been described in polyposis coli families, although the report ${ }^{3}$ of the St Mark's results initially listed very few. Later, ${ }^{26}$ four cases of carcinoma of the ampulla of Vater were added, and in the Swedish study ${ }^{5}$ several types of neoplastic diseases were encountered. These included carcinoma of the stomach, thyroid gland, pancreas, and genitourinary tract.

The results in the present series are shown in table 8. As can be seen, brain tumours and tumours of the urogenital system stand out in their frequency. No example of carcinoma of the ampulla of Vater occurred, although two cases of pancreatic carcinoma were found.

Of some interest is the fact that only one case of gastric carcinoma was found. The other malignancies were all single examples and were probably fortuitous.

Three cases of polyposis coli associated with gastric and duodenal polyps have been described. ${ }^{27}$ In two cases, biopsy confirmed them to be benign adenomas. Of these three cases, one did not have any other extracolonic manifestations, but the other two did have stigmata of the Gardner syndrome. These authors have reviewed the literature and point out that the paucity of occurrence of gastric adenomas may be because of the fact that no routine search was made. In contrast, a careful study from Tokyo ${ }^{28}$ searched for gastric lesions in cases of polyposis coli, their interest being stimulated by the high incidence of gastric cancer in Japan. They found gastric polyps in 10 of 15 cases. The frequency of gastric carcinoma in polyposis coli in Japan is low at $2.6 \%$, although the incidence of gastric carcinoma in the general population is high. The 'gastric polyps' were asymptomatic and none was pedunculated. Endoscopy and air contrast barium meals were performed in this investigation. No such thorough study of the stomach has been made previously in polyposis coli, but such a study would be valuable to compare the prevalence in the UK or USA with that in Japan, particularly in view of the different incidence of gastric cancer in these countries. In our own series 
there was only one known case of gastric carcinoma, indicating that if gastric adenomas are common in polyposis coli, they become malignant at a later age than colonic carcinoma and the tendency to malignancy is probably less. Several cases of peptic ulcer were found in our family members, but no mention was made of gastric polyps in the reports of the barium meals. All cases of polyposis coli should ideally be examined for the possibility of gastric lesions. As successful colectomy is performed more often and at younger ages, if these gastric polyps are common, gastric carcinoma may be seen more frequently in the future, as two of the three biopsied by Hoffman and Goligher ${ }^{27}$ did prove to be adenomas and presumably, therefore, premalignant.

Family 12 is unusual in having a familial occurrence of genitourinary carcinoma and polyposis coli. No such family has been previously described in the three large studies. A remarkable isolated case ${ }^{29}$ was reported of a patient who over 13 years developed adenocarcinomas of the colon secondary to polyposis coli, carcinoma of the ampulla of Vater, and a primary transitional cell carcinoma of the urinary bladder.

The term 'Gardner syndrome' has been used by some authors to include almost any abnormal feature, usually neoplastic, in association with polyposis coli. This seems to be unnecessary. The occurrence of isolated abnormalities (lymphoid hyperplasia of the ileum, adrenal carcinoma, carcinoma of the lung, etc) are probably chance associations and at present it does not serve any useful purpose to include them in an all-embracing term. The syndrome as described by Gardner in 1962 is helpful and important. It has been amply confirmed both in individual case reports and in large series, and the extracolonic manifestations are of prime importance both as an external 'marker' of the gene and in reminding the surgeon that a total colectomy and ileostomy is not always entirely curative. It is perfectly reasonable for carcinomas such as that of the lung to occur in families with polyposis coli. There is no suggestion or evidence at present to say that polyposis coli affords any degree of protection against the development of other types of neoplasia.

\section{SINGLE MEMBER FAMILIES}

Seven such sporadic cases occurred in this series (table 9). All published series have described a surprisingly large instance of such cases. Veale ${ }^{3}$ ascribed such cases to new mutations, but McConnell ${ }^{30}$ showed that a remarkably high rate of mutation would be necessary to explain this.

Of the St Mark's 98 sporadic cases, ${ }^{3}$ eight children of the probands subsequently developed the disease, and in one family a sib of the proband manifested the disease at a later date. The Japanese study ${ }^{6}$ concluded that it was not possible to support Veale's hypothesis that phenocopies do not exist.

There were two cases of the Gardner syndrome out of the seven in this series. The age of onset data do not differ significantly from the classical families; the younger age of onset of cancer is calculated from only two cases. Veale's ${ }^{3}$ finding of an increased parental age in sporadic cases was not confirmed in this study, the parental age being a little less than the parental age of the general population (table 10).

\section{Conclusion}

It would seem best to consider the Gardner syndrome in terms of a family unit rather than using it for a particular person. If even one member of the family can be regarded as having the Gardner syndrome it is always likely that other subjects will follow suit. If any person is found to have colonic adenomas and belongs to a family having the Gardner syndrome, then that person is at risk of later developing a desmoid tumour. In addition, the use of the term 'the Gardner syndrome' in a family also serves to alert the physician or paediatrician to the fact that should he come across a person in such a family who presents to him with epidermoid cysts or osteomas, then that person must be most carefully followed up for the future development of colonic adenomas. There is evidence from this study that polyps are a constant feature of expression of the gene.

With the large number of combinations of extracolonic manifestations in different members of a family, it would seem more likely that this is the result of one pleiotropic gene, rather than two genes being responsible for the two conditions.

Many different conditions resulting from multiple alleles at a common locus is another possibility. The extracolonic manifestations that develop in subjects with the gene may depend on other parts of the genotype.

I wish to thank Dr E A Murphy, Department of Medical Genetics, and Dr T R Hendrix, Department of Gastroenterology, in whose departments at the Johns Hopkins Hospital, Baltimore, polyposis coli is being studied. I am particularly indebted to Mrs Anne Krush, Department of Medical Genetics, Johns Hopkins Hospital, for her work on the pedigrees and for contacting relatives from far and wide. I also wish to thank Dr L S Levin, Department of Ear, Nose, and Throat, Johns Hopkins Hospital, for the dental examinations and radiographs. This work was performed while holding a Fellowship in Medicine at the Johns Hopkins Hospital supported by Grant CA 14925-03 from the Large Bowel Project of the National Cancer Institute. 
APPENDIX Details of the 16 families with extracolonic manifestations

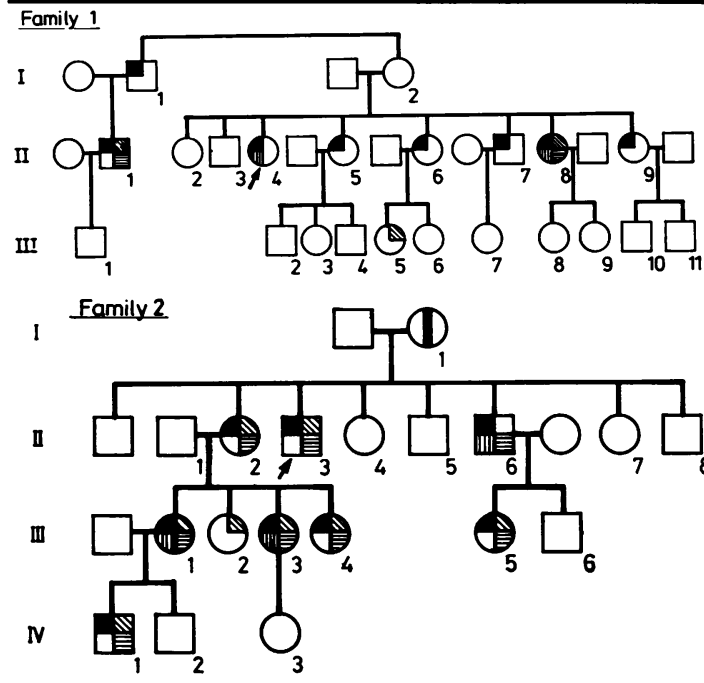

Fomily 3
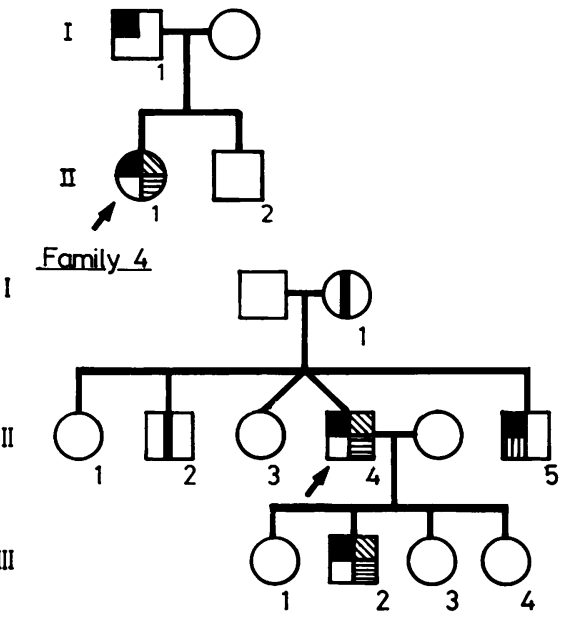

sons

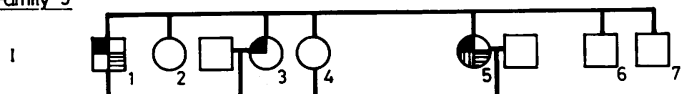

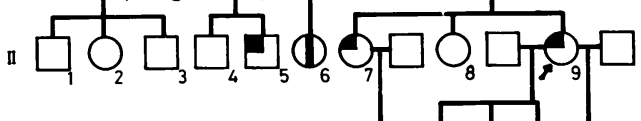
uㅣ

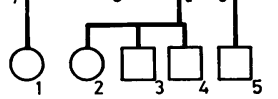
Family 8
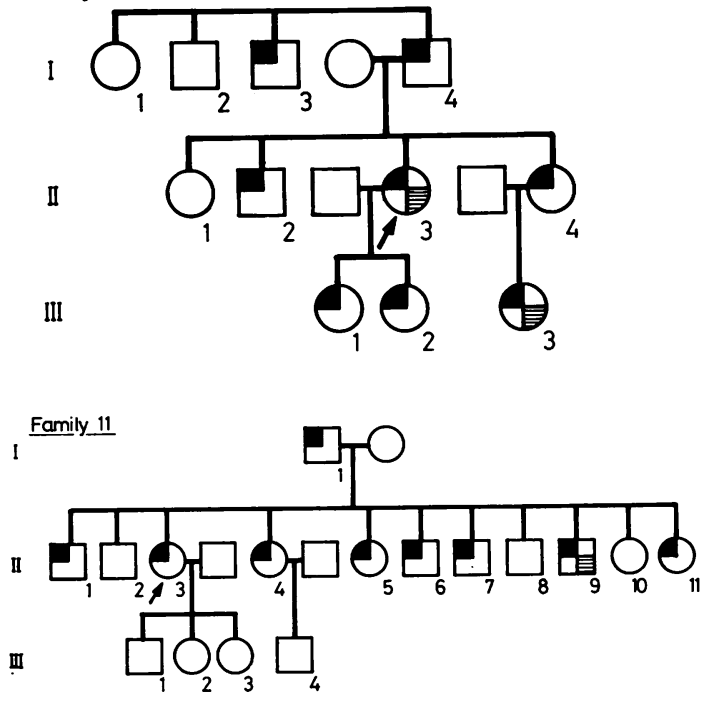

Family 13

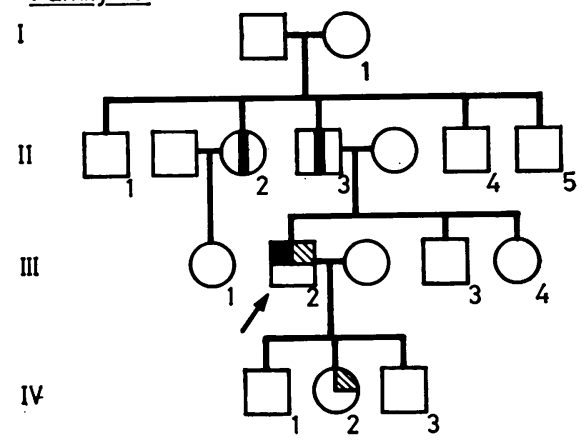

Family 14

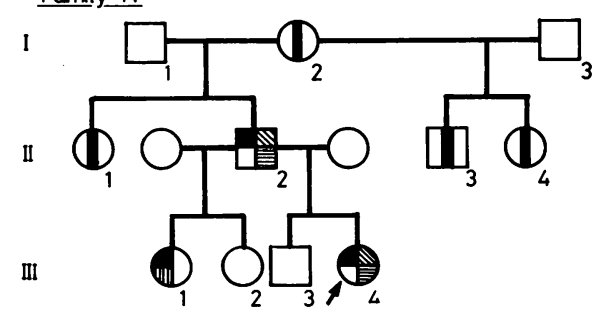

Family 7

II

I

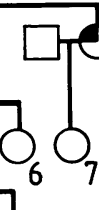

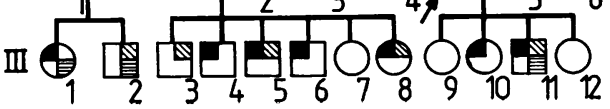



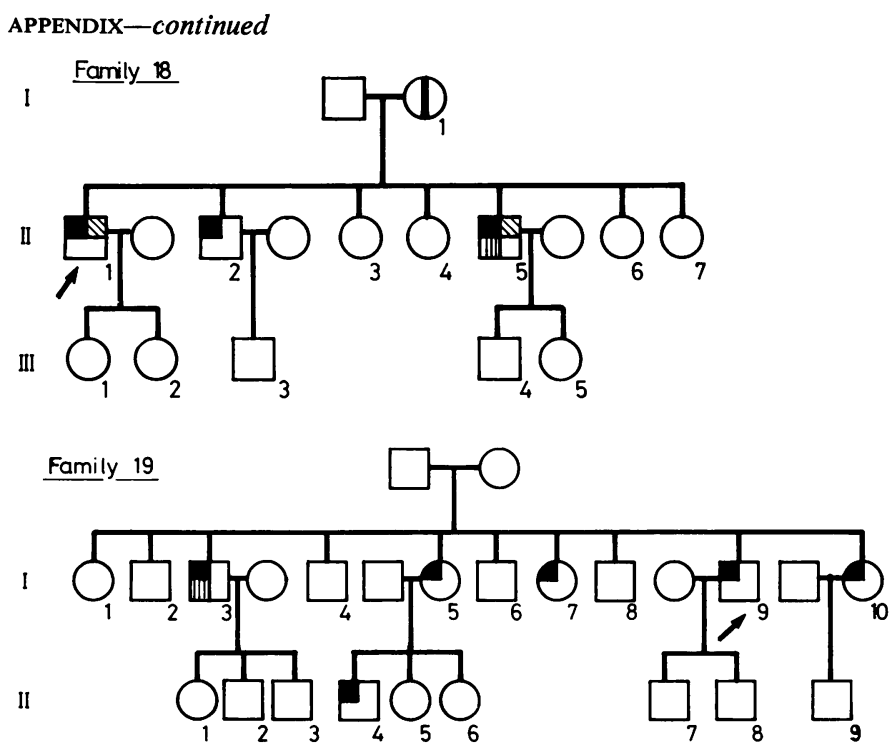

Family 22

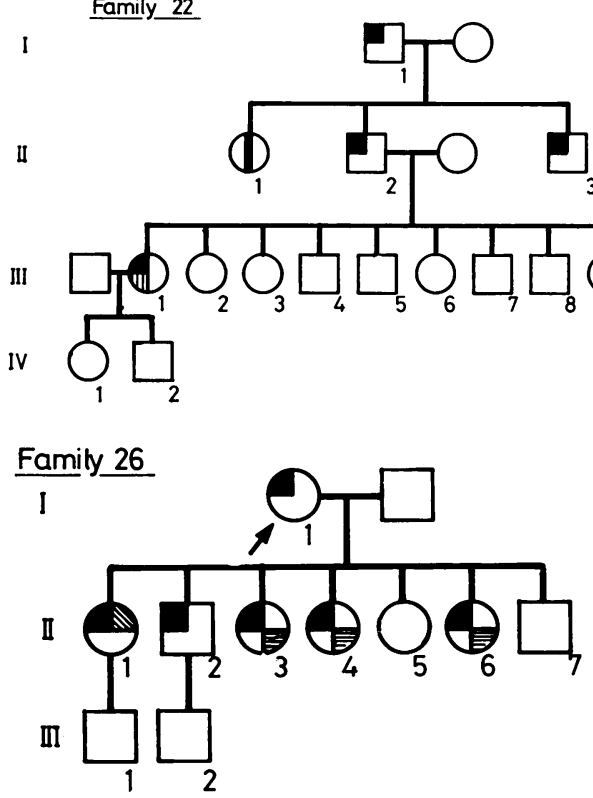

Fomily 27

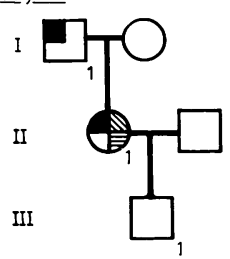

Family 26
Family 28

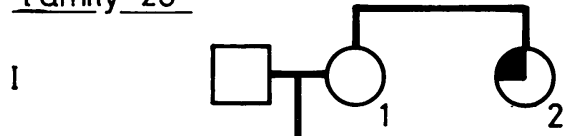

II

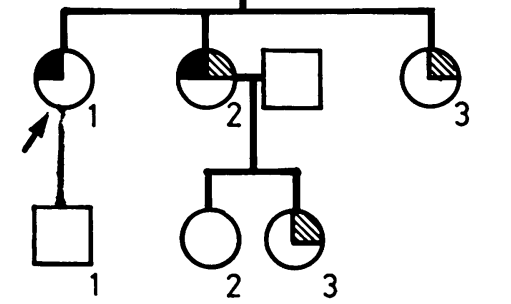




\section{References}

1 Lockhart Mummery P. Cancer and heredity. Lancet 1925; i:427-9.

2 Dukes CE. The hereditary factor in polyposis intestini or multiple adenomata. Cancer Review 1930;5:241-56.

3 Veale AMO. Intestinal polyposis. Eug Lab Mem Series No 40. London: Cambridge University Press, 1965.

4 Bussey HJR. Familial polyposis coli. Baltimore: Johns Hopkins University Press, 1975.

5 Alm T, Licznerski G. The intestinal polyposes. Clin Gastroenterol 1973;2:577-602.

6 Utsunemiya J, Iwama T, Suzuki H, et al. Heredity and polyposis coli. Stomach and Intestine 1974;9:1149-56.

7 Cabot RC. Case records of Massachusetts General Hospital. N Engl J Med 1935;212:263-7.

8 Miller RH, Sweet RH. Multiple polyposis of the colon. Ann Surg 1937;105:511-5.

- Oldfield MC. The association of familial polyposis of the colon with multiple sebaceous cysts. Br J Surg 1954;40: 534-41.

10 Gardner EJ, Richards RC. Multiple cutaneous and subcutaneous lesions occurring simultaneously with hereditary polyposis and osteomatosis. Am J Hum Genet $1953 ; 5: 139-47$.

11 Gardner EJ. Follow-up study of a family group exhibiting dominant inheritance for a syndrome including intestinal polyps, osteomas, fibromas and epidermoid cysts. Am J Hum Genet 1962;14:376-90.

12 Morson BC. The polyp-cancer sequence in the large bowel. Proc R Soc Med 1974;67:451-7.

13 Leppard BJ. Epidermoid cysts and polyposis coli. Proc $R$ Soc Med 1974;67:1036-7.

14 McAdam WAF, Goligher JC. The occurrence of desmoids in patients with familial polyposis coli. $\mathrm{Br} J$ Surg 1970;57:618-31.

15 Danes BS. Second International Symposium on Colorectal Cancer, Washington DC, 1981.

16 Morson BC, Bussey HJR. Current problems in surgery. Chicago: Year Book Medical Publishers, 1970.
17 Crail HW. Multiple primary malignancies arising in the rectum, brain and thyroid. US Navy Medical Bulletin $1949 ; 49: 123-8$

18 Turcot J, Despres JP, St Pierre F. Malignant tumours of the central nervous system associated with familial polyposis of the colon. Dis Colon Rectum 1959;2:465-8.

19 Baughman FA, List CF, Williams JR, et al. The gliomapolyposis syndrome. $N$ Engl J Med $1969 ; 281: 1345-6$.

20 Yaffee HS. Gastric polyposis and soft tissue tumours-a variant of Gardner's syndrome. Arch Dermatol 1964;89: 806-8.

21 Russell DS, Rubinstein LJ. Pathology of tumours of the nervous system. 3rd ed. London: Arnold, 1971.

22 del Regato JA, Sppjut HJ. Cancer. Diagnosis, treatment and prognosis. 5th ed. St Louis: Mosby, 1977.

${ }^{23}$ Cutler SJ, Young JL Jr, eds. Third National Cancer Survey: Incidence Data. National Cancer Institute Monograph 41, March 1975.

24 Itoh H, Ohsato K, Yao T, et al. Turcot's syndrome and its mode of inheritance. Gut 1979;20:414-9.

25 Terao H, Sato S, Kim S. Gardner's syndrome involving the skull, dura and brain. $J$ Neurosurg 1976;44:638-41.

26 Bussey HJR. Extracolonic lesions associated with polyposis coli. Proc $R$ Soc Med 1972;65:294.

27 Hoffmann DC, Goligher JC. Polyposis of the stomach and small intestine in association with familial polyposis coli. Br J Surg 1971;58:126-8.

28 Utsunomiya J, Maki T, Iwama T, et al. Gastric lesions of familial polyposis coli. Cancer 1974;34:745-54.

29 Capps WF, Lewis MI, Gazzaniga DA. Carcinoma of the colon, ampulla of Vater and urinary bladder associated with familial polyposis coli. A case report. Dis Colon Rectum 1968;11:298-305.

30 McConnell RB. The genetics of gastrointestinal disorders. Oxford: Oxford University Press, 1966.

Requests for reprints to Dr S B Cohen, Department of Medicine, Walton Hospital, Rice Lane, Liverpool L9 $1 \mathrm{AE}$. 